\title{
FLEXURAL ELASTIC BUCKLING STRESS OF BATTEN TYPE LIGHT GAUGE BUILT-UP MEMBER
}

\author{
Kazuya MITSUI ${ }^{1}$, Atsushi SATO ${ }^{2}$ \\ ${ }^{1}$ Nagoya Institute of Technology, \\ ${ }^{1}$ Nagoya Institute of Technology, Dept. of Civil Engineering, Gokiso-cho, Showa-ku, \\ Nagoya, Aichi, Japan \\ ${ }^{2}$ Frontier Research Institute for Information Science
}

\begin{abstract}
In Japan, built-up member composed with light gauge is used for studs of shear wall. Flexural buckling stress of built-up compression member is evaluated by effective slenderness ratio. The effective slenderness ratio of light gauge built-up compression member is proposed for heavy sections; however, it is not verified that it can be adopted in light gauge. In this paper, full scale testing of light gauge built-up members are conducted. From the test results, it is shown that current Standard overestimates the buckling strength. Based on energy equilibrium theory, modified effective slenderness ratio for light gauge built-up member is derived. The validity of the modified effective slenderness ratio is shown with test results.
\end{abstract}

Keywords: Light gauge, Built-up member, Buckling stress, Effective slenderness ratio

\section{GENERAL RULES}

In Japan, Technical Notification ${ }^{2}$ for a Steel Framed Housing (SFH) which is composed with light gauge member was revised in 2001 because technology for manufacturing has developed, and the light gauge members which thickness are from $0.3 \mathrm{~mm}$ to $2.3 \mathrm{~mm}$ were able to be used as main structures. Also, because

\footnotetext{
${ }^{1}$ Flexural Elastic Buckling Stress of Batten Type Light Gauge Built-up Member, Nagoya Institute of Technology, Gokiso-cho, Showa-ku, Nagoya, Aichi, Japan, +81-52-735-5200, k.mitsui.395@nitech.jp
} 
Technical Notification ${ }^{2}$ was revised, a story limit has been extended up to 4-story and middle-rise building has become possible to build. SFH model and the detail of the shear wall are shown in Fig. 1. Framing of the shear wall is light gauges and built-up members are used for the vertical members (hereinafter studs). A plaster boards and a structural plywood are screwed to this framing. The builtup compression members are usually composed with two ripped channels of the light gauge members, and these ripped channel members are connected by selfdrilling screws.

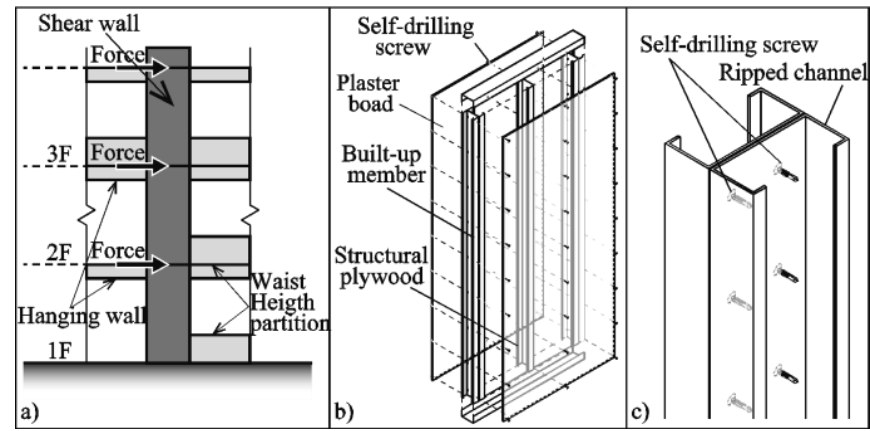

Fig. 1. a) Steel framed house, b) Components of shear wall, c) Detail of built-up member

When a lateral load subjects to SFH, because the shear wall is designed as a cantilever column, overturning moment from the upper stories will subject to the shear wall, and the overturning moment generates a high compressive axial force to the studs (built-up member) of the shear wall. As a result, there is a possibility that the flexural buckling in the un-expected direction occurs at the built-up member after peeling off the panels at ultimate limite state. The occurrence of the flexural buckling leads to the abrupt fall of the vertical bearing. And the increment of total story increases the axial force of the built-up compression member of the shear wall. In a conventional design for a low-rise building, only the safety for the flexural buckling of the full web was considered. However, in the case that the middle-rise building, it is necessary to confirm the safety for the flexural buckling of the open web.

In Japan, the flexural buckling stress of the built-up compression member is calculated by using the effective slenderness ratio that specified in the Design Standard for Steel Structure ${ }^{3}$, and this formula can be expressed as follow;

$$
\begin{gathered}
\lambda_{y e}=\sqrt{\lambda_{y}{ }^{2}+\lambda_{1}^{2}} \\
\lambda_{y}=L / i_{y} \\
\lambda_{1}=a / i_{1}
\end{gathered}
$$


where; $\lambda_{y e}$ is the effective slenderness ratio; $\lambda_{y}$ is the slenderness ratio of the builtup member acting on a unit in the buckling direction being considered; $\lambda_{1}$ is the slenderness ratio of individual component between connectors; $L$ is the length of the built-up member; $i_{y}$ is the radius of gyration of the whole section; $a$ is the length between connectors; $i_{1}$ is the radius of gyration of the individual components. This formula is based on Bleich's assumption ${ }^{4}$. However, Bleich's assumption and the effective slenderness ratio were applied for heavy section. Also, a design formula for built-up members in Eurocode ${ }^{5}$ is based on Bleich's assumption ${ }^{4}$. From this reason, it is questionable that the formula can be directly applied in the light gauge. Moreover, a bending moment distribution which is applied to Bleich's assumption has not confirmed by testing.

In this paper, to clarify the buckling strength of the light gauge built-up compression member and the bending moment distribution in the components, full-scale tests in elastic range were conducted. The moment distribution was investigated by reading strain gauges. Finally, the energy equilibrium theory was applied, and a modified effective slenderness ratio for the light gauge built-up compression members is derived. The accuracy of the proposed slenderness ratio is confirmed by comparing with test results.

\section{TEST PROGRAM}

To confirm the flexural buckling stress of the batten type built-up compression member composed with two ripped channel members (chords) in elastic range, the full-scale testing are conducted. Usually, the batten type light gauge built-up compression member is not used as the studs of the SFH. However, the batten type light gauge built-up compression member is adopted in this study because the moment distribution of the built-up member can be computed by strain gauges reading. Because the thickness is less than $2.3 \mathrm{~mm}$, the buckling modes in elastoplastic range are very complicated. Therefore, to confirm the buckling mode clearly, the target length of the specimen is within a range of elastic. Parameters are a separation between connectors $a$, a distance between the centroids of the chords $h$ and the length of the member $L$. Two or three specimens are prepared per a parameter. Fig. 2 shows the cross section of the test specimen and the whole specimens.

As shown in Fig. 2.a, two chords are interconnected by the batten plate by pretension bolts. The chords used in this study are C-89x40x22 (called 89LCN22), and its thickness is $2.2 \mathrm{~mm}$. The batten plates are designed to be remained within the range of elastic when a vertical load reaches the flexural buckling strength. Fig. 2.b shows samples of the specimens. Material properties are shown in Table 1. The geometrical dimensions of the built-up compression members is shown in Table 2. The effective slenderness ratio shown in Table 2 is 
calculated from Eq. 1.1. To guaranty the flexural buckling of the built-up member, the slenderness ratio for individual component between connectors $\lambda_{1}$ is smaller than the slenderness ratio $\lambda_{y}$.

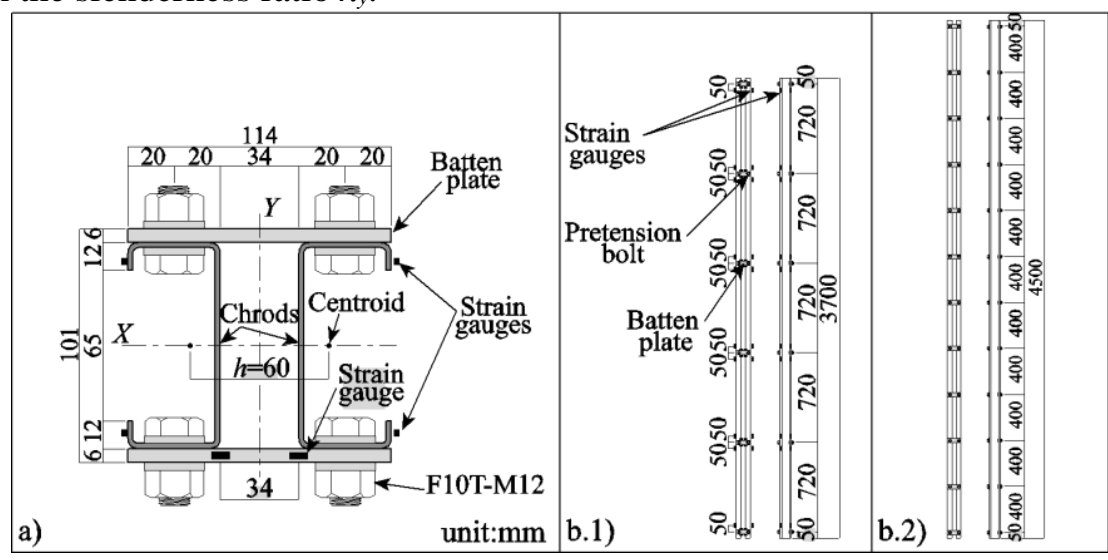

Fig. 2. Detail of the test specimen; a) Cross section of the specimen ( $h=60 \mathrm{~mm}$ series);

b) Whole specimen of; b.1) L3700a720h60; b.2) L4500a400h60

Test setup is shown in Fig. 3. Both end of the specimen is supported by pin devices that are allowed to rotate only in the buckling direction. The buckling length of the specimen is equal to the length $L$. The buckling direction is equal to the weak axis of the built-up member. The hydraulic jack is used to apply the axial force at the centroid of the built-up member.

Table 1. Material properties from coupon tests

\begin{tabular}{|l|l|l|l|l|}
\hline Parts & $E\left(\mathrm{~N} / \mathrm{mm}^{2}\right)$ & $f_{y}\left(\mathrm{~N} / \mathrm{mm}^{2}\right)$ & $f_{u}\left(\mathrm{~N} / \mathrm{mm}^{2}\right)$ & $Y . R .(\%)$ \\
\hline Chord & 201600 & 306 & 456 & 67.1 \\
\hline Batten & 213100 & 309 & 446 & 69.3 \\
\hline
\end{tabular}

where: $E$ is Young's modulus; $f_{y}$ is the yield stress; $f_{u}$ is the ultimate stress; Y.R. is the yield ratio

Table 2. Geometrical dimensions of the built-up compression member

\begin{tabular}{|c|c|c|c|c|c|c|c|c|c|c|}
\hline Name & $\begin{array}{c}L \\
(\mathrm{~mm})\end{array}$ & $\begin{array}{c}A \\
\left(\mathrm{~mm}^{2}\right)\end{array}$ & $\begin{array}{c}i_{1} \\
(\mathrm{~mm})\end{array}$ & $\begin{array}{c}a \\
(\mathrm{~mm})\end{array}$ & $n$ & $\begin{array}{c}h \\
(\mathrm{~mm})\end{array}$ & $\begin{array}{c}I \\
\left(\mathrm{~cm}^{4}\right) \\
\end{array}$ & $\lambda_{y}$ & $\lambda_{1}$ & $\lambda_{y e}$ \\
\hline L3700a400h60 & \multirow[t]{6}{*}{3700} & \multirow[t]{6}{*}{792} & \multirow[t]{6}{*}{14.8} & 400 & 9 & 60 & 95.76 & 106 & 27 & 132 \\
\hline L3700a720h50 & & & & 720 & 5 & 50 & 72.69 & 122 & 49 & 167 \\
\hline L3700a720h60 & & & & 720 & 5 & 60 & 95.45 & 106 & 49 & 146 \\
\hline L3700a1200h50 & & & & 1200 & 3 & 50 & 72.57 & 122 & 49 & 180 \\
\hline L3700a1200h60 & & & & 1200 & 3 & 60 & 95.38 & 106 & 81 & 160 \\
\hline L3700a1200h70 & & & & 1200 & 3 & 70 & 129.0 & 94 & 81 & 148 \\
\hline L4500a400h60 & \multirow[t]{3}{*}{4500} & \multirow[t]{3}{*}{792} & \multirow[t]{3}{*}{14.8} & 400 & 11 & 60 & 95.67 & 129 & 27 & 157 \\
\hline L4500a880h50 & & & & 880 & 5 & 50 & 27.98 & 147 & 60 & 203 \\
\hline L4500a880h60 & & & & 880 & 5 & 60 & 95.62 & 129 & 60 & 177 \\
\hline
\end{tabular}


where: $A$ is the area of the specimens; $n$ is the number of panels $(=L / a) ; i_{1}$ is the radius of gyration of individual components; $h$ is the distance between centroids of chords; $I$ is the moment of inertia of the built-up member acting on a unit in the buckling direction being considered

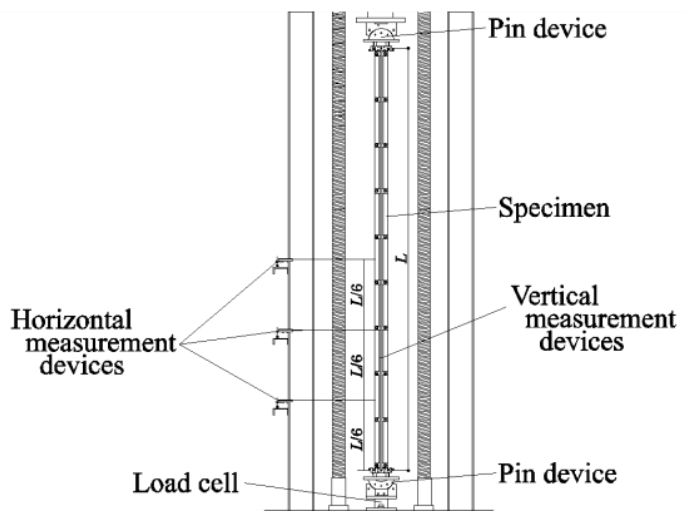

Fig. 3. Test setup

\section{TEST RESULTS}

Table 3 summarizes the test result. Fig. 4 shows relationships between nondimensional buckling stress and vertical deformation. Fig. 5 shows photographs of the flexural buckling deflection after loading.

Firstly, the maximum load of all the specimens are determined by flexural buckling, and the flexural buckling deflection occurred at the maximum load. Torsional buckling or local buckling are not observed before the maximum load. Also, from reading strain gauges at the batten plates, the batten plates were retained within a range of elastic. Therefore, in this paper, the maximum strength is defined as the flexural buckling strength. After the flexural buckling, with the progress of the flexural deflection, the load decreased gradually. And, with the increment of distance between connecters (batten plates), the flexural buckling stress decreased. This effect was caused by reduction of the stiffening of the batten plates.

The distributions of the bending moment at the flexural buckling strength are shown in Fig. 6. These distributions are calculated by reading strain gauges and equilibrium of the bending moment at each connection. The aspect ratio is changed to confirm the distribution easily, and the bending moment of the batten plates were smaller than that of chords. Therefore, the bending moment of the batten plates are illustrated by ten times larger. The distribution of the bending moment at the chords are mostly single curvature, which is totally different from Bleich's assumption shown in Fig. 6.b. 
Table 3. Test results of the batten type light gauge built-up compression member

\begin{tabular}{|l|c|l|l|l|l|l|l|}
\hline Name & Mark & \multicolumn{3}{|c|}{$\exp P_{\max }(\mathrm{kN})$} & \multicolumn{3}{|l|}{$\exp f_{\max }\left(\mathrm{N} / \mathrm{mm}^{2}\right)$} \\
\hline L3700a400h60 & $\times$ & 92.5 & 99.6 & 106.5 & 117 & 127 & 136 \\
\hline L3700a720h50 & $\boldsymbol{\Delta}$ & 65.8 & 66.3 & & 84 & 85 & \\
\hline L3700a720h60 & $\Delta$ & 72.9 & 83.1 & 77.2 & 92 & 106 & 99 \\
\hline L3700a1200h50 & $\bullet$ & 53.4 & 53.9 & & 68 & 69 & \\
\hline L3700a1200h60 & $\circ$ & 69.1 & 72.5 & 72.0 & 87 & 93 & 92 \\
\hline L3700a1200h70 & $\otimes$ & 92.1 & 84.4 & & 118 & 108 & \\
\hline L4500a400h60 & $\diamond$ & 89.6 & 72.5 & 62.4 & 113 & 93 & 80 \\
\hline L4500a880h50 & $\square$ & 53.0 & 47.5 & & 68 & 61 & \\
\hline L4500a880h60 & $\square$ & 53.0 & 58.5 & & 68 & 75 & \\
\hline
\end{tabular}

where: $\exp _{\max }$ is the flexural buckling strength; $\exp _{\max }$ is the flexural buckling stress.
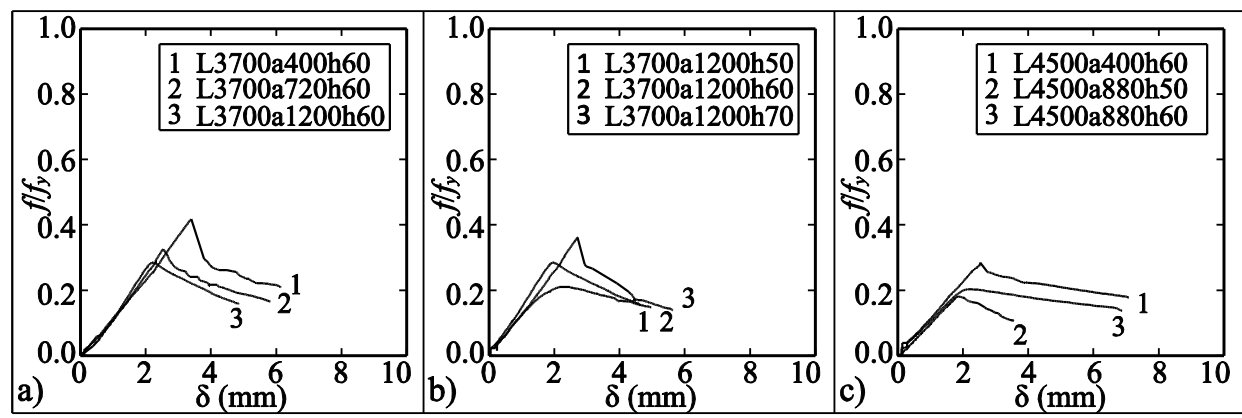

Fig. 4. Relationships between non-dimensional buckling stress and vertical deformation; a) L3700h60 series; b) L3700a1200 series; c) L4500 series
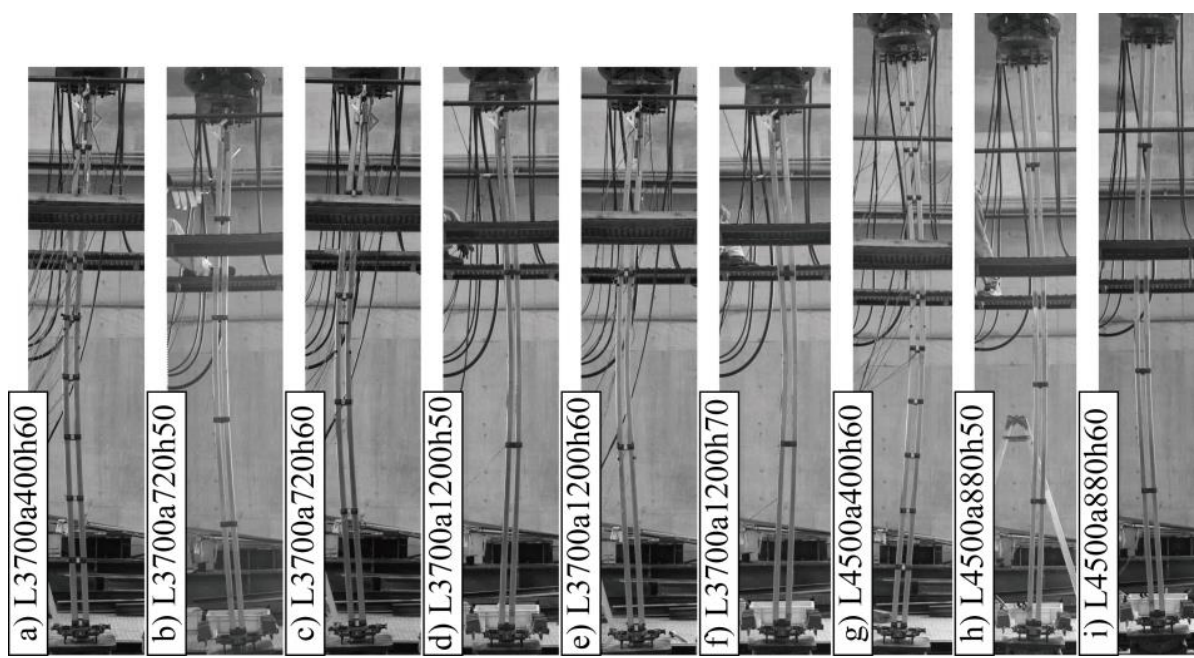

Fig. 5. Flexural buckling deflection after loading 


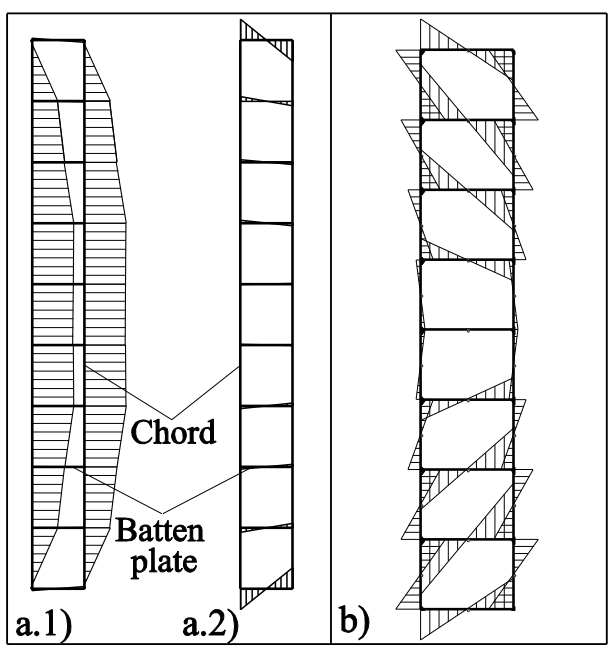

Fig. 6. Distribution of the bending moment

a) L3700a400h60; a.1) Chords;

a.2) Batten plates $(\times 10)$;

b) Bleich's assumption

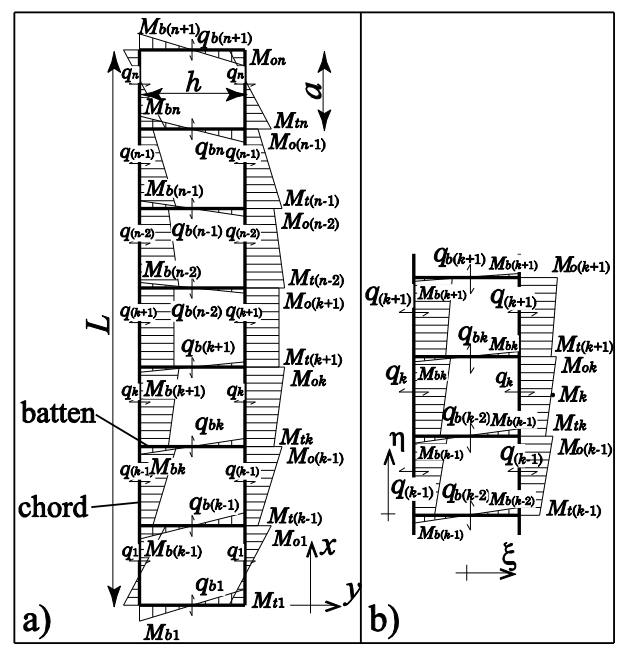

Fig. 7. Bending moment distribution model;

a) Proposed moment distribution;

b) Detail of the coordinate

\section{EVALUATION OF FLEXURAL BUCKLING STRESS}

The effective slenderness ratio in the Design Standard for Steel Structures is derived from Bleich's assumption shown in Fig. 6.b. As mentioned in Fig. 6, the bending moment distribution due to the flexural buckling observed in testing was totally different from Bleich's assumption. Therefore, it can be assumed that difference of the moment distribution leads to inadequate evaluation. Fig. 7 shows the bending moment distribution model due to the flexural buckling.

This model is based on the test observation. The purpose of this study is to propose modified effective slenderness ratio pro $\lambda_{y e}$ for light gauge based on the test observation. In this paper, energy equilibrium theory was used to derive the effective slenderness ratio pro $\lambda_{y e}$. Modified effective slenderness ratio for batten type light gauge built-up compression member is derived as follow.

$$
V=2 V_{1}+2 V_{2}+V_{3}+2 V_{4}+V_{5}
$$

where: $V$ is the strain energy due to the deflection; $V_{1}$ is the strain energy caused by the axial force $F_{k}$ in the individual chord; $V_{2}$ is the strain energy caused by the local bending at the individual chord; $V_{3}$ is the strain energy caused by the local accumulated at the batten plates; $V_{4}$ is the strain energy due to the shear force which occurs at bending in the chords; $V_{5}$ is the strain energy due to the shear 
force which occurs at bending in the batten plates. Considering a pin-ended column, the deflected axis of the column is assumed as a half sin wave. And, the work done by the external force is expressed by Eq. 4.3.

$$
\begin{gathered}
u=f \cdot \sin \frac{\pi}{L} x \\
W=\frac{P_{c}}{2} \int_{0}^{L}\left(\frac{d u}{d x}\right)^{2} d x=\frac{\pi^{2} P_{c} f^{2}}{4 L}
\end{gathered}
$$

where: $W$ is the work done by the external force. $P_{c}$ is the flexural buckling strength; $f$ is the amplitude of the flexural deflection. Based on the energy condition, the work done by the external force $W$ is equal to the strain enegy $V$.

$$
V=W
$$

The bending moment $M_{a l l, k}$ at the point $x=(2 k-1) L / 2 n$, which is corresponding to the middle point of a panel $k-1$, is expressed as follow;

$$
M_{a l l, k}=P_{c} \cdot u=P_{c} \cdot f \cdot \sin \frac{\pi}{L} x
$$

The shear force acting on the chord for the same reference point is expressed by $E q$. 4.6. Also, the shear force acting on the batten plate of joint $k$ is expressed by $E q$. 4.7. where; $\zeta$ is the coefficient which decides the amount of the shear force acting on the batten plates.

$$
\begin{gathered}
q_{k}=\frac{1}{2} \cdot \frac{d M_{a l l, k}}{d x} \\
q_{n k}=P_{c} f \zeta \cos \frac{k-1}{n} \pi
\end{gathered}
$$

The bending moment at any joint of the chord member $k$ is expressed as follow;

$$
\begin{gathered}
M_{t k}=a \sum_{j=1}^{k-1} q_{j}-\frac{h}{2} \sum_{j=1}^{k} q_{b j} \\
=\frac{P_{c} f}{4 \sin \pi / 2 n}\left(\frac{a \pi}{l} \sin \frac{k-1}{n} \pi-h \zeta \sin \frac{2 k-1}{2 n} \pi-h \zeta \sin \frac{1}{2 n} \pi\right)
\end{gathered}
$$

Considering the equilibrium of the bending moments acting on joint from 1 to $k$, the bending moment at any point of the chord member is expressed as follow; 


$$
M_{k}=q_{k} \eta+M_{t k}
$$

As the change of the axial force $F_{k}$ in the between panels points $k-1$ and $k$ caused by the flexural deflection in the state of the buckling is expressed by $F_{k}=M_{k} / h$, the strain energy $V_{1}$ is expressed as follow;

$$
V_{1}=\frac{1}{2} \sum_{k=1}^{n} \int_{0}^{a} \frac{F_{k}^{2}}{E A_{1}} d \eta=\frac{L P_{c}^{2} f^{2}}{4 E A_{1} h^{2}}
$$

By similar procedures, the strain energy are given by Eqs. 4.11-14.

$$
\begin{gathered}
V_{2}=\frac{1}{2} \sum_{k=1}^{n} \int_{0}^{a} \frac{M_{k}^{2}}{E I_{1}} d \eta \\
=\frac{L P_{c}^{2} f^{2}}{16 E I_{1}}\left[-\frac{\pi^{2} a^{2}}{6 L^{2}}+\frac{1}{\pi^{2} a}\left\{\frac{h^{2}}{2 a}\left(2 L^{2}+\pi^{2} a^{2}\right) \zeta^{2}-2 \pi L h \zeta+\pi^{2} a\right\}\right] \\
V_{3}=\frac{1}{2} \sum_{k=1}^{n} \int_{-h / 2}^{h / 2} \frac{M_{b k}^{2}}{E I_{b}} d \xi=\frac{P_{c}^{2} f^{2} h^{3} L}{48 E I_{b} a} \zeta^{2} \\
V_{4}=\frac{1}{2} \sum_{k=1}^{n} \int_{0}^{a} \frac{\kappa_{1} q_{k}^{2}}{G A_{1}} d \eta=\frac{\pi^{2} \kappa_{1} P_{c}^{2} f^{2}}{16 L G A_{1}} \\
V_{5}=\frac{1}{2} \sum_{k=1}^{n} \int_{-h / 2}^{h / 2} \frac{\kappa_{b} q_{b k}^{2}}{G A_{b}} d \xi=\frac{\kappa_{b} P_{c}^{2} f^{2} h L}{4 G A_{b} a}
\end{gathered}
$$

where: $I_{b}$ is the moment of inertia of the batten plates; $A_{b}$ is the area of the batten plates; $\kappa_{1}$ is the shear coefficient of individual components; $\kappa_{b}$ is the shear coefficient of the batten plates; $G$ is the shear modulus. Using Eqs. $4.1-4.14$, the energy conditions is expressed by $E q .4 .15$, and the buckling strength can be expressed as follow by solving for $P_{c}$;

$$
\begin{aligned}
& V=\frac{L P_{c}^{2} f^{2}}{4 E I} \cdot \alpha \\
& P_{c}=\frac{\pi^{2} E I}{L^{2}} \cdot \frac{1}{\alpha}
\end{aligned}
$$




$$
\begin{gathered}
\alpha=\left(\frac{2 I}{A_{1} h^{2}}+\frac{I}{2 I_{1}}\left[-\frac{\pi^{2} a^{2}}{6 L^{2}}+\frac{1}{\pi^{2} a}\left\{\frac{h^{2}}{2 a}\left(2 L^{2}+\pi^{2} a^{2}\right) \zeta^{2}-2 \pi L h \zeta+\pi^{2} a\right\}\right]\right. \\
\left.+\frac{I h^{3}}{12 I_{b} a} \zeta^{2}+\frac{\pi^{2} E I \kappa_{1}}{2 L^{2} G A_{1}}+\frac{E I \kappa_{b} h}{G A_{b} a} \zeta^{2}\right)
\end{gathered}
$$

The buckling stress $\sigma_{c}$ can be expressed by $\sigma_{c}=P_{c} / 2 A_{1}$; the effective slenderness ratio can be expressed as follow;

$$
{ }_{\text {pro }} \lambda_{y e, 0}=\sqrt{\alpha} \cdot \lambda_{y}
$$

Because the terms of fraction in Eq. 4.17 from third to the last are small compared with the first terms and the second terms of fraction in Eq. 4.17, and these terms can be negligible. The coefficient $\zeta$ can be obtained by solving Eq. 4.19.

$$
\partial P_{c} / \partial \varsigma=0
$$

Using Eq. 4.17, Eq. 4.18 and Eq. 4.19, the modified effective slenderness ratio is expressed as follow;

$$
\begin{aligned}
{ }_{\text {pro }} \lambda_{y e} & =\sqrt{\frac{I}{I_{0}} \lambda_{y}{ }^{2}+\frac{\pi^{2} \varphi}{12} \lambda_{1}{ }^{2}} \\
\varphi & =1+3 \frac{2-(\pi a / L)^{2}}{2+(\pi a / L)^{2}} \\
I_{0} & =I-2 I_{1}=\frac{A_{1} h^{2}}{2}
\end{aligned}
$$

where: $\varphi$ is the modified factor; $I_{0}$ is the moment of inertia of the built-up member which is computed based on the geometrical shape. Comparison between buckling stress curve and test results are shown in Fig. 8. The horizontal axis of Fig. 8.a is based on the effective slenderness ratio Eq. 1.1, and the horizontal axis of Fig. $8 . b$ is based on the modified effective slenderness ratio Eq. 4.20. Each marks are shown Table 3. 


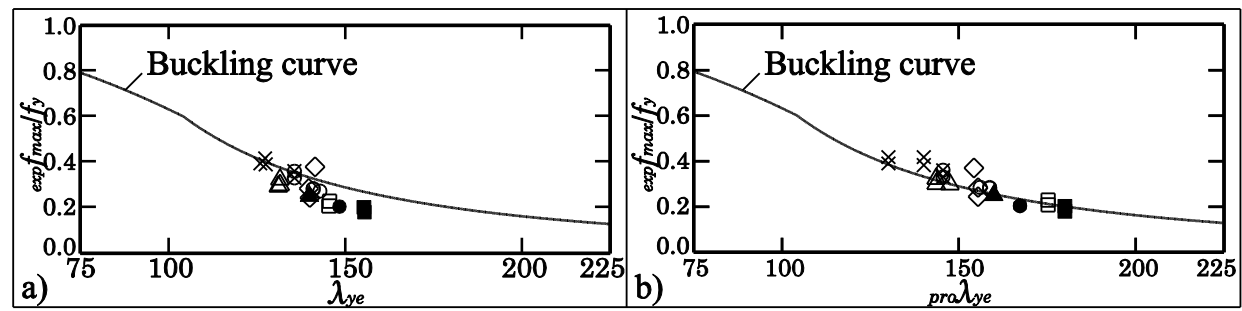

Fig. 8. Comparison between column curve and test results; a) Evaluated by the effective slenderness ratio; b) Evaluated by the modified effective slenderness ratio

The results evaluated by the effective slenderness ratio based on the Design Standard for Steel Structure are un-conservative results as shown Fig. 8.a; the buckling stress of the built-up member are overestimated. On the other hand, the results evaluated by the modified effective slenderness ratio get close to the buckling stress curve, and good agreements or improved results were observed. The modified effective slenderness ratio is adequately evaluating the flexural buckling stress of the batten type light gauge built-up member. The modified effective slenderness ratio can apply to the built-up members, which have more than 3 equal interval (the distance between batten plates), composed with light gauge. To guaranty the flexural buckling of the built-up member, the slenderness ratio for individual component between connectors $\lambda_{1}$ should be smaller than the slenderness ratio $\lambda_{y}$. Also, to remain within an elastic range, the modified effective slenderness ratio should be more than 100 .

\section{CONCLUSION}

In this paper, full-scale testing was conducted to clarify the flexural buckling stress of batten type light gauge built-up member, and the modified effective slenderness ratio based on test observation was proposed.

Following results were found.

1. Bending moment distribution at the chords were computed from strain gauges reading, and the distribution was totally different from Bleich's assumption. Although Bleich's assumption was double curvature bending at the chords, single curvature bending was observed from the testing.

2. Un-conservative results were observed from all test results when the flexural buckling stress were evaluated by the Design Standard for Steel Structure.

3. Good agreements or improved results were observed when the flexural buckling stress were evaluated by the modified effective slenderness ratio. 


\section{REFERENCES}

1. Ministry of Land, Infrastructure, Transport and Tourism: Ministry of Land, Infrastructure, Transport and Tourism Notification No. 1641, Japan, 2001.

2. Japan iron and steel federation: Design Manual for Light Gauge Structure, 2014.

3. Architectural Institute of Japan: Design Standard for Steel Structures - Based on Allowable Stress Concept, fourth edition, Japan, 2005

4. Freidrich Bleich: BUCKLING STRENGTH OF METAL STRUCTURES, $2^{\text {nd }}$ edition, McGraw-Hill Book Company, inc., 1952.

5. CEN (European Communities for Standardization): EN 1993-1-1 Eurocode 3: design of steel structures - Part 1: general rules and rules for buildings, 2005.

\section{SPREZŻYSTE NAPREŻENIA KRYTYCZNE ZGIĘCIOWEJ FORMY WYBOCZENIA WBUDOWANYCH, DWUGAŁEZIOWYCH SŁUPÓW PRZEWIAZZKOWYCH WYKONANYCH Z LEKKICH ELEMENTÓW CIENKOŚCIENNYCH}

\section{Streszczenie}

W systemowych rozwiązaniach budynków szkieletowych jako słupki wbudowane w ścianę stosuje się lekkie elementy cienkościenne. Typowy słupek składa się z dwóch gałęzi wykonanych z lekkich elementów cienkościennych zespolonych za pomocą przewiązek łączonych za pomocą śrub samowiercących. W badanym rozwiązaniu, nośność na wyboczenie giętne jest określana na podstawie efektywnej smukłości definiowanej w Normie Projektowania Konstrukcji Stalowych opartej na koncepcji naprężeń dopuszczalnych. Smukłość efektywna w tym podejściu normowym koresponduje $\mathrm{z}$ założeniem Bleicha stosowanym zazwyczaj do elementów grubościennych. Powstaje zatem wątpliwość czy podana w normie koncepcja smukłości efektywnej może być także stosowana dla lekkich elementów cienkościennych.

W pierwszym etapie badań wykonano pełnoskalowe badania eksperymentalne, których celem było wyjaśnienie wspomnianej kwestii. Elementami badanymi były słupy dwugałęziowe wykonane z lekkich elementów cienkościennych łączonych między sobą przewiązkami. Wyniki badań pokazały, że obowiązująca Norma przeszacowuje nośność wyboczeniową takich elementów. Korzystając z metod energetycznych wyprowadzono zmodyfikowany wzór na smukłość efektywną. Poprawność wyprowadzonego wzoru na smukłość efektywną pokazano porównując otrzymane nośności wyboczeniowe z wynikami eksperymentów. Porównania te potwierdziły poprawność szacowania nośności wyboczeniowej dwugałęziowych, lekkich elementów cienkościennych pod warunkiem zastosowania wyprowadzonego wyrażenia na smukłość efektywną.

Słowa kluczowe: lekki przekrój cienkościenny, element wbudowany, naprężenia krytyczne, smukłość efektywna

Editor received the manuscript: 06.07.2016 